\title{
Microplastics as an emerging hazard to terrestrial and marine ecosystems: Sources, Occurrence and Analytical Methods
}

\author{
Khawla Chouchene ${ }^{1, *}$, and Mohamed $\mathrm{Ksibi}^{1,2}$ \\ ${ }^{1}$ Laboratory of Environmental Engineering and Ecotechnology (LGEET-ENIS), Sfax, Tunisia \\ ${ }^{2}$ Higher Institute of Biotechnology of Sfax (ISBS), Tunisia
}

\begin{abstract}
Microplastics (MPs) with particles lower than $5 \mathrm{~mm}$ in size, are crucial pollution of increasing ecotoxicological concern in the environments. Lately, studies on MPs have been documented globally due to increasing awareness of the potential risks for human health and for the environment. However due to limitations of different analytical methods and environmental assessment risk, MPs distribution and biological effects are still database topics. To clarify this gap, this study brings out a wide range of scientific literature related to MPs studies in different environmental compartments as well as sediments, oceans, coastlines, uptake and the health effect. The environmental and health risk related to microplastic contamination is still unclear.
\end{abstract}

\section{Introduction}

Plastic materials facilitating the daily life for people, reach up million tons of production each year. Plastic pollution was emerging issue reveal adverse effects in the surrounding environment. Their fears ultimately reached the society, therefore, policy makers started drafting the first regulations to alleviate the problems (EU Directive 2019/904). According to the statistics reported by Plastics Europe (the Association of Plastics Manufacturers in Europe), global plastic production was estimated to be $3.6 \times 10^{8}$ tons as in 2019 [1] and it was assessed that the annual plastic production be up 33 billion tons with waste plastic generation of $6.9 \mathrm{Mt}$ by the year of 2050 . Not merely the $22 \%$ incineration, $25 \%$ recycled and $42 \%$ of oppressive treated, but also, plastic entire generated $15 \%$ of greenhouse gas emission [2]. Besides the eruption of Covid-19 pandemic, peoples drawing an increase in the personnel equipment protective (gloves and masks), where plastics and rubbers are the most components. In this pandemic situation, Bown. (2019) has reported that the plastic production in China has been increased by $450 \%$ from 20 to 110 million [3].

This greater quantity of microplastics with different shapes lead to many toxicity responses for primary consumers and potentially lead to cascade effects on the trophic web [3]. Prolonged exposure to weathering conditions (UV radiations, hydrolysis, mechanical/physical processes) plastic being emitted into environment in countless particle

* Corresponding author: chouchene.khawla23@gmail.com 
size called microplastics "MPs" by gradually fragmentation/degradation processes [4]. MPs was classified in 2011 by the United Nations Environment Program (UNEP) as a new emerging issue touching human health worldwide. With no scientifically agreed on definition of MPs size, studies have defined MPs as any particles $<5 \mathrm{~mm}$ in length ([4], [5]).

A subset of plastics $<1 \mu \mathrm{m}$ were referred to nanoplastics and a size ranged between 5 to $25 \mathrm{~mm}$ were identified as mesoplastic, while a size more than $25 \mathrm{~mm}$ is considered as macroplastics according to the classification reported by the European Union's Marine Strategy Framework Directive (MSFD). Mismanagement or inappropriate disposal of solid wastes led to the accumulation of MPs on broad range of concentration in terrestrial and aquatic compartment. In addition, MPs have been detected in air samples, food and drinking water ([6]; [7]; [8]). Recently, MPs have been detected in plants tissues. In fact, through the physical barriers of intact plant tissue absorb MPs and transfer it to edible part of the plant ([9]; [10]) and their inference for human health via inhalation of small fibrous of indoor airborne or ingestion have been reviewed [8]. MPs are universally released directly/indirectly in marine and terrestrial environments as primary (abrasive product) or secondary categories (fragmented large litter) by wide range transport such as rivers, wind and ocean movement [4]. Ocean movement reinforces the widespread of MPs from the pole to the equators, reach the depth [11], ranging from Irish continental shelf [12], Atlantic Ocean [13], Pacific Ocean [14], Mediterranean Sea [15], even to the Iceland [16]. For instance, MPs were detected in the salt and tap water [5]. In these environmental media, PE and PP were the main manufactured polymers detected up to date [5]. MPs with smile size act as vector of exogenous substances potentially toxic elements, non-polymerized polymers, hydrophobic organic pollutant and their own contaminated additives ([17]; [18]; [19]) and transferred to organisms after ingestion and then caused harmful effects [18]. Published studies lead to rethink that MPs could pose a serious threat to the whole environmental systems, global biodiversity, and human health.

In addition, other research has been carried out on the distribution patterns of MPs by many analytical methods to measure the MPs occurrence in water systems, sediments, and soils. Separation, identification, and quantification also were included. This information on the global scale is highly lacking due to limitations in the number of surveys. The aims of this review are to better understand the main sources of MPs, review the analytical methods for the detection and quantification of MPs, highlights the impact of MPs on the marine organisms and to give a snapshot picture of several ideas for future research.

\section{Source of MPs}

Nowadays, marine pollution caused by MPs originates from diverse sources. The majority of MPs entering to the sea is considered from land-based sources. MPs were generally disposed into the marine environment in aggregates of different shapes, colors, sizes and compositions. The land-based source dominated the input of both MPs primary and secondary into oceans [20]. Sea-based sources were attributed to the fishing activities, offshore industry and shipping sectors [21]. It was estimated that during fishing and aquaculture gears including PE net, lost, abandoned and worn-out of plastics, easily contribute to the introduction of MPs into the oceans that damage the aquatic habitat. Several studies have recovered that secondary MPs had dominated the marine environments inputs due to the constant fragmentation of large plastics [22].

\subsection{Primary microplastic}

Primary MPs are tiny particles $<5 \mathrm{~mm}$ in size, originated from engineered micro-sized plastic beads and industrial production which are widely used for commercial formulations, 
such as cosmetics (make-up, sunscreen), personal care production and abrasives as well as toothpaste, facial cleansers [23]. In addition, primary MPs are originated from other applications, released from textiles as microfibers shed, clothing manufacture and fishing nets [24]. These particles were hardly picked up and visible to the naked eye, likely were easily escape capture by wastewater treatment (primary sewage treatment screens), ultimately ended up in the marine environment [21]. Another considerable source of primary MPs was the tire abrasion with $5-10 \%$ estimation of global MPs contribution, entering the aquatic environment [25].

\subsection{Secondary microplastic}

Secondary MPs are particles arise from the fragmentation and degradation of large plastic pieces into extremely small particles sized through many processes like solar UV radiation, mechanical abrasion, mechanical (photolytic) and biological process. Thus, such a very small particles, could be directly transported from rivers, sewage and shorelines to the marine environment. Usually, long exposure to sunlight and weathering, MPs become more surface brittle thus, embrittlement degradation processes lead to yellowing the plastic debris [17]. Polyethylene "PE" particles in the pelagic waters showed loss weighting from 1 to $7 \%$ within one month by three marine bacteria [27]. As consequence, biopolymers, bioderived and biobased plastics, could not be completely degraded into smaller particles, which bring harms threat to the ocean environment [21]. MPs could be further degrading into nanoparticles with lower bound size which are already detected in the ocean [26],

\section{Methods and materials}

\subsection{Extraction and separation methods}

Extraction process differs for sediment/soil and surface seawater. For water, MPs can be directly separated using a net or directly collected by filter. For that a known volume water is filtered then MPs were separated by visual pick up [28]. For sediment and soil, separation was achieved by floatation, which is the common method, wherein MP is frequently extracted by a higher density salt solution. Saturated $\mathrm{NaCl}\left(1.2\right.$ g.cm- $\left.{ }^{3}\right), \mathrm{ZnCl}_{2}(1.5-1.7$ g.cm- $\left.{ }^{3}\right)$, NaI $\left(1.6-1.8\right.$ g.cm- $\left.{ }^{3}\right)$, and $\mathrm{CaCl}_{2}\left(1.5\right.$ g.cm- $\left.{ }^{3}\right)$ have been used as the most solutions to float MPs from sediment and soil, especially $\mathrm{NaCl}$ and $\mathrm{CaCl}_{2}$ by the low cost [29]. Separation of plastic extraction using salts solutions of different densities are showed in the table 1.

Table 1 : Density separations of different polymers using in MPs extraction according to HidalgoRuz et al. (2012) and Prata et al. (2019)[30][32].

\begin{tabular}{cccccc}
\hline Polymer & Density & Water & NaCl & NaI & ZnCl2 \\
\cline { 3 - 6 } & g.cm-3 & $\mathbf{1}$ g.cm-3 & $\mathbf{1 . 2}$ g.cm-3 & $\mathbf{1 . 6 - 1 . 8}$ & $\mathbf{1 . 5 - 1 . 7}$ \\
& & & & g.cm-3 & g.cm-3 \\
PE & $\mathbf{0 . 9 2 - 0 . 9 7}$ & + & + & + & + \\
PP & $\mathbf{0 . 9 - 0 . 9 1}$ & + & + & + & + \\
PS & $\mathbf{1 . 0 4 - 1 . 1}$ & - & + & + & + \\
PET & $\mathbf{1 . 3 7 - 1 . 4 5}$ & - & - & + & + \\
PA & $\mathbf{1 . 0 2 - 1 . 0 5}$ & - & + & + & + \\
Polyester & $\mathbf{1 . 2 4 - 2 . 1}$ & - & - & + & + \\
PVC & $\mathbf{1 . 1 6 - 1 . 5 8}$ & - & \pm & + & + \\
PVA & $\mathbf{1 . 1 9 - 1 . 3 1}$ & - & \pm & + & + \\
\hline
\end{tabular}




\begin{tabular}{|c|c|c|c|c|c|}
\hline Acrylic & 1.09-1.2 & - & + & + & + \\
\hline $\mathbf{P U}$ & 1.2 & - & + & + & + \\
\hline POM & $1.41-1.61$ & - & - & \pm & + \\
\hline Alkyd & $1.24-2.1$ & - & - & + & + \\
\hline Toxicity & & Low & Low & High & High \\
\hline
\end{tabular}

Label: +: effective separation; -: not separated; \pm : possible extracted.

Polymers: PE: polyethylene, PP: polypropylene, PS: polystyrene; PA: polyamide (nylon), POM: polyoxymethylene, PVA: polyvinyl alcohol, PVC: polyvinylchloride, PET: polyethylene terephthalate, PU: polyurethane

Acid and alkali solvents, or oxidizing agents, including $\mathrm{NaOH}(56 \%$ or $52.5 \mathrm{M}), \mathrm{KClO}$ $(30 \%), \mathrm{HNO}_{3}(65 \%$ or $22.5 \mathrm{M}), \mathrm{H}_{2} \mathrm{SO}_{4}(96 \%)$ and $\mathrm{H}_{2} \mathrm{O}_{2}(30 \%$ or $32.6 \mathrm{M})$, have been used to digest and remove organic matter from floatation. However, $\mathrm{HNO}_{3}$ and $\mathrm{H}_{2} \mathrm{O}_{2}$ were the usually employed [28]. Nevertheless, many of these agents reduce the MPs number and weight, as well as the digestion by $\mathrm{HNO}_{3}$ and $\mathrm{H}_{2} \mathrm{O}_{2}$ is reducing MPs numbers by 2-7\% [10]. Besides acid, alkali and oxidizing agents, enzymatic digestion could be also used [31] [32] (Table.2).

Table 2 : comparison of different digestion methods for MPs removal from complex environment samples according to Companale et al. (2020) and Prata et al. (2019).

\begin{tabular}{|c|c|c|c|c|c|}
\hline Digestion & Reagents & Treatment method & Hazard & Pros & Cons \\
\hline Acid & $\mathrm{HNO}_{3}$ & $\begin{array}{c}22.5 \mathrm{M}, 2 \mathrm{~h} \approx 100^{\circ} \mathrm{C} . \\
35 \%, 1 \mathrm{~h} 60^{\circ} \mathrm{C} . \\
65 \% \text {, RT overnight } \\
\text { and } 2 \mathrm{~h} 60^{\circ} \mathrm{C} \text {. } \\
\mathrm{HNO}_{3}(5-69 \%), \mathrm{RT} \\
96 \mathrm{~h} .\end{array}$ & $\begin{array}{l}\text { Oxidizer } \\
\text { corrosive }\end{array}$ & $\begin{array}{c}\text { Efficient in } \\
\text { organic } \\
\text { digestion }\end{array}$ & $\begin{array}{l}\text { - Degradation of PE, } \\
\text { PP and PS } \\
\text { - Yellowing } \\
\text { - PA degradation } \\
\text { - Fusion of PET } \\
\text { - Melted PE and PP } \\
\text { - Coloring change in } \\
\text { PET, PVC and PP }\end{array}$ \\
\hline \multirow[t]{3}{*}{ Alkali } & $\begin{array}{l}\mathrm{HCL} \\
\mathrm{HNO}_{3} \\
\\
\mathbf{N a O H}\end{array}$ & $\begin{array}{l}20 \%, 96 \mathrm{~h} 25-60^{\circ} \mathrm{C} . \\
55 \% \text {, RT } 1 \text { month. } \\
1 \text { h } 60^{\circ} \mathrm{C}\end{array}$ & $\begin{array}{l}\text { Acute } \\
\text { toxicity } \\
\text { Corrosive } \\
\text { No }\end{array}$ & $\begin{array}{l}82 \% \\
\text { efficient } \\
\mathbf{9 4 \%}\end{array}$ & \multirow[t]{3}{*}{$\begin{array}{l}\text { - Polymer } \\
\text { degradation } \\
\text { - Change in PVC } \\
\text { and PET }\end{array}$} \\
\hline & $\mathrm{K}_{2} \mathrm{~S}_{2} \mathrm{O}_{8}$ & $10 \mathrm{M}, 24 \mathrm{~h} 60^{\circ} \mathrm{C}$ & & & \\
\hline & $\mathrm{KOH}(1 \%)$ & $\begin{array}{l}0.27 \mathrm{M}+0.24 \mathrm{M} \\
\mathrm{NaOH}, 24 \mathrm{~h} 65^{\circ} \mathrm{C} \\
\text { RT 3 weeks } \\
24 \mathrm{~h} 64^{\circ} \mathrm{C} \\
96 \mathrm{~h} 50^{\circ} \mathrm{C} \\
96 \mathrm{~h} 40^{\circ} \mathrm{C} \\
\text { RT } 2 \text { days }\end{array}$ & & & \\
\hline Oxidative & $\mathrm{H}_{2} \mathrm{O}_{2}$ & $\begin{array}{l}30 \%, 1 \mathrm{~h} 60^{\circ} \mathrm{C}, 7 \mathrm{~h} \\
100^{\circ} \mathrm{C} . \\
35 \% \text {, RT, } 96 \mathrm{~h} 40^{\circ} \mathrm{C} . \\
35 \% \text {, RT, } 96 \mathrm{~h} 50^{\circ} \mathrm{C} .\end{array}$ & $\begin{array}{l}\text { Corrosive } \\
\text { harmful }\end{array}$ & Efficient & $\begin{array}{l}\text { Degradation of } \\
\text { polymers at high } \\
\text { concentration }\end{array}$ \\
\hline Enzymatic & $\begin{array}{l}\text { Corolase } \\
7086 \\
\text { Tripsin }\end{array}$ & $\begin{array}{l}1 \mathrm{~h} 60^{\circ} \mathrm{C} \\
30 \min 38-42^{\circ} \mathrm{C}\end{array}$ & No danger & $\begin{array}{l}\text { Good } \\
\text { inorganic } \\
\text { and } \\
\text { biological } \\
\text { digestion }\end{array}$ & Expensive \\
\hline
\end{tabular}

Recently, pressurized fluid extraction has been used to extract the MPs under specific conditions (temperature and pressure) using solvents with different polarities (methanol, 
hexane, dichloromethane). Solvents were then removed by evaporation [28]. A new approach for MPs removal from wastewater treatment is still recommended to avoid the microplastic contamination in the effluent, the removal of MPs by membrane technologies including ultrafiltration, reverse osmosis, flocculation, biological treatment and membrane bioreactor, is still the aim of research. The most performance technology was in the MPs removal are showed when applied the membrane bioreactor, which showed a significance removal achieved 99\% [33]. In urban, Coagulation removal and photocatalytic degradation were considered as the cost- and energy-effective techniques, that have drawn growing attention to remove MPs from urban waters [34].

\subsection{Microplastics identification}

Identification and quantification of MPs were almost suspected by visual inspection, followed by chemical characterization. Visual inspection directly or by stereo microscope allows to identify the MPs based on their physical characteristics. Fourier-transform infrared spectroscopy (FTIR) and Raman spectroscopy are suitable techniques for MPs identification based on well-known infrared absorption bands representing distinct chemical functionalities present in the material. Lipophilic dyes can be used to visualize microplastics under a fluorescence microscope [4]. Microplastics Identification by Pyrolysis Gas Chromatography Mass Spectrometry (py-GCMS) have been used to analyze MP samples from surface waters, karst waters, and sediments [19]. Researchers improve the plastic classification and misclassification by prodding particles via needles [32], that could allow to the plastic classification by shape, size and types. Staining dyes is a low-cost method to facilitate the visual identification. Insufficient results have been reported for Rose Bengal, Hostasol yellow 3G, Eosin B and oil red EGN [35], that the problem were arise on the affinity to dye the MPs and their effects of staining the biogenic materials. Presently, Rose-Bengal allows a $92 \%$ coloration of MPs with $25 \mu \mathrm{m}$ in size, Nile Red staining provides high recovery rates by $96.6 \%$ [35]. Thus, these methods might provide to researchers the time effective tool to identify and select the MPs particles to be submitted to chemical identifications.

MPs particles were identified based on their size by Raman spectroscopy ( $2 \mathrm{~mm})$, time gated Raman method spectroscopy (125 mm and 5 mass\%), Micro-Raman spectroscopy (>100 mm), ATR-FTIR spectroscopy (>100 mm) [4], $\mu$-Raman spectroscopy (>1 mm), macroscopic dimensioned nearinfrared (NIR) in combination with chemometrics $(>10 \mathrm{~mm}$ and 1 mass $\%)$ and hyperspectral imaging technology (0.5-5 mm) [36]. Pyrolysis-gas chromatography coupled with mass spectrometry (PY-GC-MS) [37] and thermal extraction desorption gas chromatography mass spectrometry (TED-GC-MS) can be used as one for MPs identification and associated organic plastics additives [38]. The advantage of this method is the use of relative highly simple masses and measurement of heterogeneous matrices, that ease the identification and the quantification of MPs without preselection. Scanning electron microscope "SEM" coupled to the energy-dispersive X-ray has been used to collect more information on the MPs morphology, while this method requires a preselection and mounting of the analyzed MPs.

\section{Global distributions of microplastics}

Primary and secondary MPs are distributed across all oceans ([39]; [40]), sediments ([4]; [17]; [41], bottom sediments [42], beaches and coastlines [22] and the knowledge on MPs distribution has rapidly increased to date. 


\subsection{Beaches, coastlines and shorelines}

Mediterranean Sea is one of the most worrisome area of the world, impacted by a higher microplastic concentration more than that reported from the North Pacific area [15] contains $5-10 \%$ of the global plastic mass, almost $20 \%$ of the total floating plastic. Recently the number of particles floating in the surface water of Mediterranean Sea peak up to $8.400 .000 \mathrm{p} / \mathrm{km}^{2}$ which, the small size $<500 \mu \mathrm{m}$ dominate the total [44]. Piperagkas et al. (2019) have explained this distribution by the environment factors as well as the winds, influencing their own properties (shapes, size, colors, etc.) [45]. The study conducted on Caribbean beaches at Lesser Antilles by Bosker et al. (2018) showed a concentration at the range of $261 \mathrm{~kg}$ dry weigh (d.w) [46]. Similar to these studies, approximately, 5.25 trillion particles weighing 268940 tons float in the world's oceans surface [47]. MPs have been reported along various beaches as well as Yellow sea, China [48]; Nallathanni Island, Gulf of Mannar, India [49]; Aveiro beach of Portugal [50]; France [51] and Turkey [52]. These beaches were mostly characterized by touristic zones, which obviously attract MPs pollution. These studies focused on the level of contaminations and explained the source and the types of plastics recovered. Fibers were often being the principal dominate shape from the total of MPs pollution, following by fragments ([47], [4], [17], [50]).

\subsection{Oceans distributions}

MPs particles have been detected on the surface and subsurface waters of Atlantic Ocean ([53], [40]), North-eastern Pacific Ocean ([54], [39]), Arctic Polar waters [55], as well as in surface waters of the North Sea [56], Adriatic [57], Bohai and South China Seas ([58], [59]). Small size facilities the distribution of MPs in the open oceans, which the size of MPs detected in the North Atlantic Ocean, ranged between 0.41 to $420 \mathrm{~mm}$ in length [22] other research showed that MPs in the size range between 300 to $750 \mu \mathrm{m}$ were transferred by wind to $95 \mathrm{Km}$ [60]. the occurrence and distribution of MPs increases when the size of particles has decreased [50]. while few studies revealed the MPs distribution on the Indian ocean, Arctic and Antarctic oceans surfaces. Hence, further studies are recommended that these unexplored zones as future research.

\subsection{Lakes, rivers, and estuaries}

Several studies have investigated the abundance and distribution of MPs in water sources such as lakes, rivers and estuaries. These studies included the coastal beach in Korea [61], the south-eastern coast of Australia [62], various estuaries in China ([63], [64]), the Dutch River Delta in Netherlands [65], the Goiania Estuary [66], the Gulf of Mexico Estuary [67], Khark Island in Iran [68], Atrato Delta in Colombia [69] and Ottawa River, Canada [70]. The influence of industrial wastes and effluents have been investigated. MPs abundance through a various river as well as the Rhine-Main area in Germany [71], Seine in Paris [72], Raritan in New Jersey [73], and Saigon in Vietnam [74] have been also assessed. As per our understanding, fibers were the dominant bulk of MPs shape, which have identified as PP, PE, and PET [47].

\subsection{Soils}

MPs detection is usually difficult in the sediments and soil samples due to the higher contain of organic matter, dark colors and nature of sediments/soils. For this raison, the use of the dyes (Nile red, eosin B, etc.) staining method and deposit feeders (Asian clam) ingest particles as indicator of MPs have recently gained attention ([4],[75]). Large quantities of 
MPs are present in soils. According to Geyer et al. (2017) [76], 6300 million tons of plastic waste were produced between the years 1950 and 2015, which 4977 million tons were accumulated in landfills. In addition, a concentration between 125 and 850 tons of MPs per million habitats are annually added to the European agriculture soils via the application of sewage sludge [47]. Aside from that, MPs has been observed in agricultural soils. MPs enter the soils by multiple sources. Greenhouse, fertilizers and mulching plastic were widely used for improving the crops growth also mulch films $(8-50 \mu \mathrm{m})$, freezing thawing process and compost were the main source to accumulating the plastic residue in the farmlands, aided by physical, chemical and biological process, these residues slowly breakdown to massive quantity of MPs [5]. The highest MPs distribution in the soil layers was influenced by land use, agriculture and landscape patterns related to the population of catchment area with higher groundwater table, lakes and coarse soil [5]. Because of the plastic mulches, orchards and greenhouse, MPs were increased in the top layer of soils in small size ranged between 0.05 to $1 \mathrm{~mm}$, mostly were fibers $92 \%$ [77]. Recent publications have indicated that animals during movements can transport MPs from the surface to the deep soil layers, then by flow MPs were transported from soils to underground water as well as the riverbank [9]. Although, MPs have the potential to alter the soil properties and interact with their biota such as earthworms and soil collembolans [78]. Liu et al. (2017) investigated the effect of MPs on soils contents by analyzing the dissolved organic nitrogen (DON), dissolved organic carbon (DOC), dissolved organic phosphorus (DOP), ammonium $\left(\mathrm{NH}_{4}{ }^{+}\right)$and phosphate $\left(\mathrm{PO}_{4}{ }^{3-}\right)$ [79]. The distribution of MPs in soil have been yet poorly understood, that could help research to mitigate the impact of MPs.

\subsection{Microplastics from other sources}

Large quantities of MPs were detected on the discharge of wastewater treatment plant and these are let into the rivers, treated wastewaters are often a route for MPs to enter the marine environment [22] due to their excessive release. Corradini et al. (2019) conducted an investigation on the abundance of MPs in the agriculture soils [80]. They concluded that the MPs detected were due to the sludge disposal on lands. Van Weert et al. (2019) demonstrated that sludge-treated soils contained a large quantity of MPs [81]. Sutton et al. (2016) showed apart of wastewater treatment plants other sources affected the San Francisco Bay area and may cause entering a significant amount of MPs into the aquatic environment [82]. Liu et al. (2019) and Horton et al. (2017) reported that storm water runoff was one of the sources for persistent MPs ([83],[84]). In addition, MPs were brought from various sources as well as residential and industrial wastes as well as municipal solid waste and storm water runoff [22].

Research on the supraglacial debris on the Italian Alps of the Northern Hemisphere showed the presence of MPs [85]. The study conducted by [86] on Siberian regions from the Atlai mountains to the Artic, confirm the presence of fibers as the main shape of MPs in the snow. Their study claimed that human activities such as dumping garbage on the mountain tops cause percolations of MPs deposition on the glaciers. Also, adventure sports and trekking on the mountain tops lead to MPs deposition. Authors feel that due to the global warming the ice trends to melts, transferring the MPs debris into the rivers, ultimately to oceans.

Atmospheric deposition is another source for MPs which remains poorly understood. MPs have been measured in atmospheric fallout in Paris [87] and in China [59]. Results obtained showed high concentrations in air. Atmospheric deposition was considered as a source for MPs into freshwater system and marine environment [22]. Several studies observed and gave a quantitative and qualitative description of the suspended MPs in the surface of air ocean and remote area $([60],[5])$. Due to their inhalation and interactions with 
other pollutants (heavy metals), MPs are considered as an emergent complex of air pollution.

\subsection{Polymers distribution}

MPs are issued polymers manufactured for different purposes and their distributions are in relation with morphological and chemical compositions [22]. Analysis of MPs were discovered the presence of different kind of polymers such as PE, PP, PET, PS in large numbers, while the other polymers such as nylon, silicon, PVC, Nitrile and other copolymer were also identified in lesser numbers [88]. Olefins, PS, PET, PVC, nylon, polyamide and polyurethane were the most dominating particles of MPs distributed in all environment compartments [1].

PE is commonly used in fishing activities [89], plastic bags and bottles, food packaging and agriculture films [90]. PP is usually used in plastic containers, pipes and carpets [90]. However, the other polymers were also generally observed in MPs distributions and their sources are not well recorded. MPs shapes as fibers and fragments are frequently recovered from the intestines and stomachs of organisms [47]. The future studies should take aim to identify the possible sources of these kind of MPs detected since this information will enable the policy makers to offer management measures.

\subsection{Uptake of microplastics by biota}

Several research studies have exhibited the uptake of MPs by marine organisms. Due to toxicological risk associated with these small particles, ingestion of MPs by biota represents a growing concern. Ingestion has been considered as the fundamental pathway for marine species to uptake the MPs. Many studies have detected the presence of MPs in the stomachs and intestines of several organisms such as fish ([91], [92], [93]), shellfish [94], zooplankton [95], invertebrates [96] and marine mammals (Nelms et al., 2018). Jovanovic et al. (2018) and Koongolla et al. (2020) showed that ingestion of MPs was occurred indirectly misidentifications or indiscriminate consumption or indirectly through the web food [97].

Adverse impact of MPs has been investigated through both laboratory and field-based experiments. According to study carried out on blue mussel cells and tissues showed a significance effect of high-density polyethylene [98]. Similarly, Li et al. (2016) examinated the ingestion of MPs on mussel Mytilus edulis from coastline of China, showed that fibers were the predominate particles followed by fragments [99]. Thus, mussel Mytilus edulis could be used as bioindicator for MPs detection if the coastline environment. Other studies showed that fibers ingestion constitute $66-71 \%$ of total MPs ingestion followed by fragments and pellets ([100],[52]).

\section{Effect of microplastic on Human health}

Ingestion of Sea food is major route for human exposure to MPs. The effect of MPs in the human systems was reported through the ingested of these contaminated particles as food [31]. Various studies have reported the presence of MPs in sugar (0.44 MPs/g), in salt, 0.11 $\mathrm{MPs} / \mathrm{g}$, in alcohol $0.03 \mathrm{MPs} / \mathrm{g}$ and in bottled water $0.09 \mathrm{MPs} / \mathrm{g}$ [101]. In addition, human could uptake $80 \mathrm{~g}$ of MPs via plants (fruits and vegetables) [31]. Polymers were well known to migrate from the gastrointestinal tract to other body parts, as well as the polystyrene can reach the human placenta and passes through blood-brain barrier, which causes systemic exposure [102]. 
Interaction of adsorbed toxic chemicals such as bisphenol A and phthalates and heavy metals on the eroded MPs surface create a great damage to human systems. Generally, the effect of MPs on human health depends on the concentration, age, chemical species, genetics, sex, and nutritional state exposed to and there is no estimation on the amount of injected MPs via food or atmosphere due to the limited evidence [103]. However, the impact of these particles on the human body were demand some factors such as the length, shapes, polymer types and chemical additives [104]. In example, longer fiber has been showed a biopersistence and resistance from the lungs while the smaller one was easily cleared, which causes primary inflammatory effect and secondary genotoxicity [105]. Considering the polymer type, PS with size lower than $50 \mathrm{~nm}$ have greater impacts such as cytotoxic and genotoxic effects on pulmonary epithelial cells and macrophages (Calu-3 and THP-1) [31].

\section{Conclusion}

This review points up the current state of knowledge and research gaps about MPs pollution in different environmental compartment. MPs in the marine environment has long been a developing research field, generally focused on the abundance, identification, and their ingestion by biota, as well as adsorption of different environmental pollutants, such as heavy metals onto these surfaces. MPs uptake by aquatic biota has been investigated for different organisms, particularly in intestine and stomachs of various fish species and invertebrates. However, this field merits further investigations summarized as follow:

Not enough knowledge regarding the toxicity of MPs implicated in human health, however, this toxicity may potentially influence by physical and chemical properties (size, length, types, adsorbed contaminants, and particles components) and exposure concentration. The effects of MPs on the human health are required to better understand, in example through the pathogenesis exposure.

\section{References}

1. PlasticsEurope (Association of Plastics Manufactures), 2019. Plastics-the facts. An analysis of European plastics production, demand and waste data. Available online at:. https:// www.plasticseurope.org/application/files/9715/7129/9584/FINAL_web_version_ Plastics_the_facts2019_14102019.pdf Accessed 16 August 2020

2. J. Zheng, S. Suh, Nat. Clim. Chang. 9, 374-378 (2019)

3. P.C. Bown, In: www.piie.comblogstrade-and-investment-policy-watchcovid-chinasexports- medical-supplies-provide-ray-hope, Accessed 14 May 2020

4. K. Chouchene, J.P. da Costa, A. Wali, A.V. Girão, O. Hentati, A. C. Duarte, T. Rochasantos, M. Ksibi, Mar Pollut Bull, 146, 92-99 (2019)

5. Z. Zhang, Z. Mamat, Y. Chen, Ecotoxicol. Environ. Saf. 202,110976, (2020)

6. EFSA, EFSA Journal, 14, 4501 (2016)

7. A.A. Koelmans, H.N. Mohamed Nor, E. Hermsen, M. Kooi, S.M. Mintenig, J. De France, Water Res, 155, 410-422, (2019)

8. J.C. Prata, J.L. Castro, J.P. da Costa, A.C. Duarte, T. Rocha-Santos, M. Cerqueira, Mar Pollut Bull, 159, 111522, (2020)

9. L. Li, Y. Luo, R. Li, Q. Zhou, W.J.G.M. Peijnenburg, N. Yin, C. Tu, Y. Zhang, Nat. Sustain. 3, 929-937 (2020). 
10. M. Scheurer, M. Bigalke, Environ. Sci. Technol. 52, 3591-3598 (2018)

11. X. Peng, M. Chen, S. Chen, S., Dasgupta, H. Xu, K. Ta, M. Du, J. Li, Z. Guo, S. Bai, Persp. Let. 9, 1-5 (2018)

12. J. Martin, A. Lusher, R.C. Thompson, A. Morley, Sci Rep, 7(1), (2017)

13. A. Cózar, E. Martí, C.M. Duarte, J. García-de-Lomas, E. van Sebille, T.J. Ballatore, Sci. Adv, 3 (2017), 1600582

14. K.L. Law, S.E. Morét-Ferguson, D.S. Goodwin, E.R. Zettler, E. DeForce, T. Kukulka, G. Proskurowski, Environ. Sci. Technol, 48, 4732-4738 (2014).

15. C.G. Avio, S. Gorbi, F. Regoli, Mar Environ Res, 128, 2-11 (2017)

16. C. Loughlin, A.R. Marques Mendes, L. Morrison, A. Morley, Mar. Pollut. Bull., 164, 111976.

17. K. Chouchene, T. Rocha-Santos, M. Ksibi, Environ. Sci. Pollut. Res, (2020).

18. W.H. Li, M.F. Jian, S.L. Liu, Y.M. Jiang, Y.B. Deng, L. Zhu, EVS 41, 242-252 (2019)

19. L. Wang, Y. Zhang, Y. Liu, X. Gong, T. Zhang, H. Sun, Environ. Sci. Technol, 53, 7095-7102 (2019)

20. H.S. Auta, C.U. Emenike, S.H. Fauziah, Environ. Int. 102, 165-176 (2017)

21. J. Wang, L. Zheng, J. Li, Waste Manag. Res, 36, 898-911 (2018)

22. N. Ajith, S. Arumugam, S. Parthasarathy, S. Manupoori, S. Janakiraman, Environ. Sci. Pollut. Res, 27, 25970-25986 (2020)

23. C.L. Waller, H.J. Griffiths, C.M. Waluda, Sci. Total Environ. 598, 220-227 (2017)

24. F. Salvador Cesa, A. Turra, J. Baruque-Ramos. Sci. Total Environ. 598, 1116-1129 (2017).

25. P.J. Kole, A.J. Lohr, F. Van Belleghem, A.M.J. Ragas, Int. J. Environ. Res. Public Health 14, 1265 (2017)

26. F. Galgani, D. Fleet, J. Van Franeker. Available at: http://ec.europa.eu/environment/marine/pdf/9-Task-Group-10.pdf $\quad$ (accessed 10 September 2017)

27. K. Harshvardhan, B. Jha, Mar Pollut Bull. 77, 100-106, (2013)

28. S. Zhang, J. Wang, X. Liu, F. Qu, X. Wang, X. Wang, Y. Li, Y. Sun, TrAC Trends Anal. Chem 111, 62-72 (2019)

29. M. Claessens, L. Van Cauwenberghe, M.B. Vandegehuchte, C.R. Janssen, Mar. Pollut. Bull. 70, 227-233 (2013)

30. V. Hidalgo-Ruz, L. Gutow, R. C. Thompson, M. Thiel, Environ. Sci. Technol 46, 3060-3075 (2012).

31. C. Campanale, I. Savino, I. Pojar, C. Massarelli, V. F. Uricchio, Environ. Sustain, 12, $6755(2020)$

32. J.C. Prata, J.P. da Costa, A.C. Duarte, T. Rocha-Santos, Trac-trend anal chem (2018)

33. D. Sol, A. Laca, A. Laca, M. Diaz, Sci. Total Environ, 20,140016 (2020)

34. Q. Xu, Q.-S. Huang, T.-Y. Luo, R.-L. Wu, W. Wei, B.-J. Ni, Chem. Eng. Technol. 416, 129123 (2021)

35. T. Maes, R. Jessop, N. Wellner, K. Haupt, A.G. Mayes, Sci. Rep. 7 (2017)

36. A. Paul, L. Wander, R. Becker, C. Goedecke, U. Braun. Environ. Sci. Pollut. Res. 26, 7364-7374 (2019) 
37. F. Galgani, G. Hanke, S. Werner, L. De Vrees, ICES J. Mar. Sci. 70, 1055-1064 (2013)

38. E. Dümichen, P. Eisentraut, C.G. Bannick, A.-K. Barthel, R. Senz, U. Braun, Chemosphere, 174, 572-584 (2017)

39. E.R. Díaz-Torres, C.D., Ortega-Ortiz, L., Silva-Iniguez, A., Nene-Preciado, E.T. Orozco, Mar. Pollut. Bull. 115, 225-232 (2017)

40. L.D.K. Kanhai, R. Officer, O. Lyashevska, R.C. Thompson, I. O’Connor, Mar. Pollut. Bull. 115, 307-314 (2017)

41. F.A.E. Lots, P. Behrens, M.G. Vijver, A.A. Horton, T. Bosker, Mar. Pollut. Bull. 123, 219-226 (2017)

42. E. Esiukova, L. Khatmullina, O. Lobchuk, A. Grave, A. Kileso, M. Haseler, A. Zyubin, I. Chubarenko, Data in Brief. 30, 105635 (2020)

43. G. Suaria, C.G. Avio, A. Mineo, G.L. Lattin, M.G. Magaldi, G. Belmonte, C.J. Moore, F. Regoli, S. Aliani, Sci. Rep. 6,1 (2016)

44. O. Piperagkas, N. Papageorgiou, I. Karakassis, Estuar Coast Shelf Sci. 219, 169-175 (2019)

45. T. Bosker, L. Guaita, P. Behrens, Mar Pollut Bull, 133, 442-447 (2018)

46. Z. Akdogan, B. Guven, Environ Pollut. 254, 113011 (2019)

47. B. Zhang, D. Wu, X. Yang, J. Teng, Y. Liu, C. Zhang, Q. Wang, Mar. Pollut. Bull 141, 9-15 (2019)

48. S. Krishnakumar, S. Srinivasalu, P. Saravanana, A. Vidyasakar, N.S. Magesh, Mar Pollut Bull. 131, 547-551 (2018)

49. K. Chouchene, J.C. Prata, J. Da Costa, A.C. Armando, T. Rocha-Santos, M. Ksibi, Mar Pollut Bull. 167, 112264 (2021)

50. N. Schmidt, D. Thibault, F. Galgani, A. Paluselli, R. Sempéré, Mermex special issue, Progress in Oceanogr. 163, 214-220 (2017)

51. O. Güven, K. Gökdağ, B. Jovanović, A. E. Kıdeyş, Environ Pollut, 223, 286-294 (2017)

52. D. Debroas, A. Mone, A. Ter Halle, Sci. Total Environ. 599, 1222-1232 (2017)

53. L.M.R. Mendoza, P.R. Jones, Environ. Chem. 12, 611-617 (2015)

54. A.L. Lusher, V. Tirelli, I. O’Connor, R. Officer, Sci. Rep. 5, 1-9 (2015)

55. J.H. Dekiff, D. Remy, J. Klasmeier, E. Fries, Environ. Pollut. 186, 248-256 (2014)

56. T. Gajst, T. Bizjak, A. Palatinus, S. Liubartseva, A. Krzan, Mar. Pollut. Bull. 113, 392399, (2016)

57. W. Zhang, S. Zhang, J. Wang, Y. Wang, J. Mu, P. Wang, X. Lin, D. Ma, Environ. Pollut. 231, 541-548 (2017)

58. M. Cai, H. He, M. Liu, S. Li, G. Tang, W. Wang, P. Huang, G. Wei, Y. Lin, B. Chen, J. Hu, Z. Cen, Sci. Total Environ. 633, 1206-1216 (2018)

59. S. Allen, D. Allen, Nat. Geosci. 12, 339-344 (2019)

60. I.S. Kim, D.H. Chae, S.K. Kim, S. Choi, S.B. Woo, Environ. Contam. Toxicol. 69, 299-309 (2015)

61. S.D. Ling, M. Sinclair, C.J. Levi, S.E. Reeves, G.J. Edgar, Mar. Pollut. Bull. 121, 104110 (2017)

62. P.K. Cheung, L. Fok, P.L. Hung, L.T.O. Cheung, Sci. Total Environ. 628-629, 731-739 (2018) 
63. L. Fok, P.K. Cheung, G. Tang, W.C. Li, Environ. Pollut. 220, 407-412 (2017)

64. H.A. Leslie, S.H. Brandsma, M.J.M. Van Velzen, A.D. Vethaak, Environ. Int. 101, 133-142 (2017)

65. A.R.A. Lima, M. Barletta, M.F. Costa, Estuar. Coast Shelf Sci. 165, 213-225 (2015)

66. C.C. Wessel, G.R. Lockridge, D. Battiste, J. Cebrian, Mar. Pollut. Bull. 109, 178-183 (2016)

67. R. Akhbarizadeh, F. Moore, B. Keshavarzi, A. Moeinpour, Environ. Pollut. 220, 720731 (2017)

68. T. Correa-Herrera, M. Barletta, A.R.A Lima, L.F. Jimenez-Segura, L.B. ArangoSanchez, J. Fish Biol. 90, 1356-1387 (2017)

69. J.C. Vermaire, C. Pomeroy, S.M. Herczegh, O. Haggart, M. Murphy, Facets 2, 301314 (2017)

70. S. Klein, E. Worch, T.P. Knepper, Environ. Sci. Technol. 49, 6070-6076 (2015)

71. R. Dris, J. Gasperi, V. Rocher, M. Saad, N. Renault, B. Tassin, Chem. 12, 592-599 (2015)

72. S. Estahbanati, N.L. Fahrenfeld, Chemosphere. 162, 277-284 (2016)

73. L. Lahens, E. Strady, T.C. Kieu-Le, R. Dris, K. Boukerma, E. Rinnert, J. Gasperi, B. Tassin, Environ. Pollut. 236, 661-671 (2018)

74. L. Su, H. Cai, P. Kolandhasamy, C. Wu, C.M. Rochman, H. Shi, Environ Pollut, 234, 347-355 (2018)

75. R. Geyer, J.R. Jambeck, K.L. Sci adv. 3, 1700782 (2017)

76. B. Henry, K. Laitala, I.G. Klepp, Sci. Total Environ. 652, 483-494 (2018)

77. M.E. Hodson, C.A. Duffus-Hodson, A. Clark, M.T. Prendergast-Miller, K.L. Thorpe, Environ. Sci. Technol. 51, 4714-4721 (2017)

78. H. Liu, X. Yang, G. Liu, C. Liang, S. Xue, H. Chen, C.J. Ritsema, V. Geissen, Chemosphere. 185, 907-917 (2017)

79. F. Corradini, P. Meza, R. Eguiluz, F. Casado, E. Huerta-Lwanga, V. Geissen, Sci Total Environ. 671, 411-420 (2019)

80. S. Van Weert, P.E. Redondo-Hasselerharm, N.J. Diepens, A.A. Koelmans, Sci Total Environ. 654, 1040-1047 (2019)

81. R. Sutton, S.A. Mason, S.K. Stanek, E. Willis-Norton, I.F. Wren, C. Box, Mar Pollut Bull. 109, 230-235 (2016)

82. F. Liu, K.B. Olesen, A.R. Borregaard, J. Vollertsen, Sci Total Environ. 671, 992-1000 (2019)

83. A.A. Horton, A. Walton, D.J. Spurgeon, E. Lahive, C. Svendsen, Sci Total Environ. 586, 127-141 (2017)

84. R. Ambrosini, R.S. Azzoni, F. Pittino, G. Diolaiuti, A. Franzetti, M. Parolini, Environ Pollut. 253, 297-301 (2019)

85. M. Bergmann, V. Wirzberger, T. Krumpen, C. Lorenz, S. Primpke, M.B. Tekman, G. Gerdts, Environ. Sci. Technol. 51, 11000-11010 (2017)

86. R. Dris, J. Gasperi, M. Saad, C. Mirande, B. Tassin, Mar. Pollut. Bull. 104, 290-293 (2016)

87. P.J. Anderson, S. Warrack, V. Langen, J.K. Challis, M.L. Hanson, M.D. Rennie, Environ Pollut, 225, 223-231 (2017) 
88. M. Chen, M. Jin, P. Tao, Z. Wang, W. Xie, X. Yu, K. Wang, Environ Pollut. 242, 1146-1156 (2018)

89. K. Zhang, J. Su, X. Xiong, X. Wu, C. Wu, J. Liu, Environ Pollut. 219, 450-455 (2016)

90. K. Jabeen, L. Su, J. Li, D. Yang, C. Tong, J. Mu, H. Shi, Environ. Pollut. 221, 141-149 (2017)

91. B. Jovanovic, G. Gokda, O. Güven, Y. Emre, E.M. Whitley, A.E. Kideys, Mar. Pollut. Bull. 130, 123-131 (2018)

92. J.B. Koongolla, L. Lin, P. Yun-Feng, Y. Chang-Ping, S. Dian-Rong, S. Liu, X. XiangRong, D. Maharana, H. Jian-Sheng, L. Heng-Xiang, Environ Pollut. 258, 113734 (2020)

93. L. Tosetto, C. Brown, J.E. Williamson, Mar. Biol. 163, 199 (2016)

94. X. Sun, Q. Li, M. Zhu, J. Liang, S. Zheng, Y. Zhao, Mar. Pollut. Bull. 115, 217-224 (2017)

95. C. Scherer, N. Brennholt, G. Reifferscheid, M. Wagner, Sci. Rep. 7, 1-9 (2017)

96. S.E. Nelms, J. Barnett, A. Brownlow, N.J. Davison, R. Deaville, T.S. Galloway, P.K. Lindeque, D. Santillo, B.J. Godley, Sci Rep. 9,1075 (2019)

97. T. Naidoo T, R.C. Thompson, A. Rajkaran, Environ Pollut. 257,113635 (2020)

98. N. Von Moos, P. Burkhard-Holm, A. Kohler, Environ Sci Technol. 46, 11327-11335 (2012)

99. J. Li, X. Qu, L. Su, W. Zhang, D. Yang, P. Kolandhasamy, D. Li, H. Shi, Environ. Pollut. 214, 177-184 (2016)

100.J. Bellas, J. Martínez-Armental, A. Martínez-Camara, V. Besada, C. Martínez- Gomez, Mar. Pollut. Bull. 109, 55-60 (2016)

101.C.E. Enyoh, A.W. Verla, E.N. Verla, World Sci. News. 131, 256-267 (2019)

102.P. Wick, A Malek, D.X.M.A. Meili, L. Diener, P.A. Diener, A. Zisch, H.F. Krug, U. VON Mandach, Environ Health Perspect 118, 432-436 (2010)

103.A.W. Verla, C.E. Enyoh, E.N. Verla, K.O. Nwarnorh, Unpublished manuscript, Imo State University, Nigeria. (2019)

104.A. Lusher, P. Hollman, J. Mendoza-Hill, FAO Fisheries and Aquaculture Technical Paper. 615, (2017)

105.J. Gasperi, S. L. Wright, R. Dris, F. Collard, C. Mandin, M. Guerrouache, V. Langlois, F.J. Kelly, B. Tassin, Curr. Opin. Environ. Sci. Health. 1, 1-5 (2018) 